\title{
MURKA ALLAH ATAS KEBEBALAN SEKSUAL MANUSIA DALAM ROMA 1:18-32
}

\author{
R. F. Bhanu Viktorahadi ${ }^{1}$
}

\author{
| Faculty of Philosophy \\ Parahyangan Catholic University \\ Bandung, Indonesia
}

\begin{abstract}
:
Among the myriad of human behaviours, few may provoke the wrath of God such as that of 'sexual asininity' (pathe atimias). An expression literally meaning 'lust for impurity' or 'shameful desire', this refers to homosexual acts be they feminine or masculine. In his letter to Rome 1:18-32, Paul asserts the gravity of this sin as evoking the ire of God upon their heads, the reasons being not only this sin confronts the natural will of the Creator, but even more so for its inclination in leading human to idolatry. Paul clarifies that homosexuality is not the issue per se, but all acts in whatever form they be, should they violate God's will are displeasing to God. Paul's starting point was not that of homosexuality leading up to idolatry. On the contrary, the text quotes Paul as explaining that idolatry is the result of erroneous relationship between human and God mirrored in aberrant sexuality. Human errs due to the bond between human and God is not firm. The logical consequence of God's wrath is punishment. In other words, human's transgression brings the wrath of God. God's wrath is not part of the judgment, but a logical consequence streaming from the ill-relationship between the Creator and the creation. Punishment befalls the humankind because of the deviation of the creation's nature.
\end{abstract}

\section{Keywords:}

sexual asininity - the wrath of God $\bullet$ shameful desire $\bullet$ homosexuality • idolatry • condemnation 


\section{Prolog}

Salah satu perilaku manusia yang memicu murka Allah adalah 'kebebalan seksual' (pathe atimias). Ungkapan yang secara harafiah mengandung makna 'hasrat akan kecemaran' atau 'hasrat yang tidak terhormat' alias memalukan ini menunjuk pada perilaku homoseksual baik maskulin maupun feminin. Dalam perikop Roma 1:18-32, Paulus menegaskan bahwa dosa ini memancing murka Allah bukan hanya karena sifatnya yang melawan kodrat, melainkan lebih dari itu, dosa ini menghantar manusia pada idolatria. Paulus menegaskan bahwa perkaranya bukan hanya homoseksualitas itu, melainkan perilaku menyimpang manusia dalam wujud apapun yang berlawanan dengan kehendak Allah. Paulus tidak berangkat dari homoseksualitas guna sampai pada gagasan penyembahan berhala. Sebaliknya, dalam teks ini Paulus menunjukkan bahwa penyimpangan dalam wujud penyembahan berhala adalah akibat penyimpangan penghayatan relasi antara Allah dan manusia yang tecermin dari penyimpangan seksual. Tindakan manusia menyimpang karena relasinya dengan Allah buruk. Konsekuensi logis dari murka adalah hukuman. Dengan kata lain, kejahatan manusia berkonsekuensi murka Allah. Murka Allah ini bukanlah komponen penghakiman, melainkan konsekuensi logis buruknya relasi antara Pencipta dan ciptaan-Nya. Hukuman menimpa manusia karena penyimpangan kodrat ciptaan yang dilakukannya.

Seiring dengan arus peradababan manusia, sisi paling purba dalam diri manusia juga terus ikut bergejolak. Yang dimaksud dengan sisi paling purba itu adalah wilayah seksualitas. Di satu sisi, seksualitas menjadi wujud partisipasi aktif manusia dalam karya penciptaan-Nya. Di sisi lain, penyimpangan-penyimpangan yang terjadi di wilayah ini menimbulkan aneka macam dampak negatif. Gereja Katolik merasakan juga akibat negatif aneka macam penyimpangan seksual ini. Guna menanggapinya, dalam arti mencegah terjadinya penyimpangan itu, Gereja menerbitkan sejumlah dokumen. Yang paling mendasar adalah dari Katekismus. Sejumlah butir Katekismus Gereja Katolik (KGK) membahas penyimpangan seksualitas sebagai sesuatu yang melawan natura dan kodrat manusia.

Teks KGK 369 tentang persamaan dan perbedaan yang dikehendaki Allah (Equalitas et diversitas a Deo volite) menyatakan bahwa pria dan wanita diciptakan, artinya, dikehendaki Allah dalam persamaan yang sempurna di satu pihak sebagai pribadi manusia dan di lain pihak dalam kepriaan 
dan kewanitaannya. 'Kepriaan (virum esse)' dan 'kewanitaan (mulierem esse)' adalah sesuatu yang baik dan dikehendaki Allah: keduanya, pria dan wanita, memiliki martabat yang tidak dapat hilang, yang diberi kepada mereka langsung oleh Allah, Penciptanya. Keduanya, pria dan wanita, bermartabat sama "menurut citra Allah". Dalam kepriaan dan kewanitaannya mereka mencerminkan kebijaksanaan dan kebaikan Pencipta. ${ }^{2}$

Butir lain dari KGK menyorot langsung homoseksualitas sebagai penyimpangan yang bertentangan dengan Hukum Kodrat. Tradisi, dengan bersandarkan Kitab Suci, yang menampilkannya sebagai penyimpangan berat, selalu menyatakan bahwa "tindakan-tindakan homoseksualitas menurut kodratnya yang intrinsik adalah buruk". Tindakan-tindakan itu bertentangan dengan hukum kodrati, menyisihkan anugerah hidup dari tindakan seksual (KGK 2358).

Guna menjelaskan penyimpangan seksualitas secara lebih relevan, Kongregasi Ajaran Iman Vatikan menyatakan dengan bahwa dalam Kitab Suci tindakan homoseksualitas itu ditolak sebagai kesesatan berat, bahkan dikedepankan sebagai akibat menyedihkan penolakan terhadap Allah. Pendapat Kitab Suci ini memang tidak mengizinkan kesimpulan bahwa semua yang menderita kelainan ini bertanggung jawab secara pribadi atasnya, tetapi bahwa tindakan homoseksual menurut hakikatnya buruk, dan tidak pernah dengan cara apapun disetujui (Declaratio de quibusdam questionibus ad sexualem ethicam spectantibus, SC Pro Doctrina Fidei, 29-121975)..$^{3}$

Paus Fransiskus juga melihat relavitisme dalam hal gender sebagai suatu tantangan bukan saja bagi Gereja, melainkan bagi kehidupan manusia pada umumnya. Dalam Seruan Apostolik Pascasinode 19 Maret 2016, Amoris Latitia (Sukacita Kasih), Paus Fransiskus mengungkapkan bahwa tantangan muncul dari berbagai bentuk ideologi, yang lazim disebut gender, yang "menyangkal perbedaan dan hubungan timbal balik alami antara laki-laki dan perempuan". Ideologi ini membayangkan sebuah masyarakat tanpa perbedaan seksual, dan merongrong dasar antropologi keluarga. Ideologi ini mengarah kepada program pendidikan dan pendoman legislatif yang mempromosikan identitas pribadi dan keintiman emosional, yang secara radikal terlepas dari perbedaan biologis antara laki-laki dan perempuan. Akibatnya, identitas manusia menjadi pilihan individu, yang bisa berubah dengan berjalannya waktu. Secara tegas, Paus Fransiskus menyerukan supaya umat beriman jangan sampai jatuh ke dalam dosa karena berusaha 
menggantikan Sang Pencipta dalam hal perbedaan gender yang senyatanya adalah given itu.

Sebagai landasan ajaran Gereja, Kitab Suci dengan tegas menghukum tindakan-tindakan homoseksual "sebagai kebejatan moral yang sungguhsungguh" (bdk. Rom. 1:24-27; 1Kor. 6:10;1Tim. 1:10). Penilaian Kitab Suci ini tidak mengizinkan untuk menyimpulkan bahwa semua yang menderita karena kelainan itu secara pribadi bertanggung jawab atas hal itu, tetapi ia menegaskan bahwa pada kenyataannya tindakan-tindakan homoseksual itu secara intrinsik buruk. Pendapat moral yang sama ditemukan pada begitu banyak pengarang-pengarang Kristen dari abad-abad pertama dan secara bulat diterima oleh Tradisi Katolik. ${ }^{4}$

Tulisan ini memberikan uraian atas Rom. 1:18-32 sebagai konteks dari Rom. 1:24-27 yang secara eksplisit mengungkapkan sikap Allah terhadap homoseksualitas yang disebut sebagai "kebebalan seksual". Tafsiran atas perikop tersebut memberikan penjelasan sikap Allah terhadap "kebebalan seksual" tersebut.

\section{Rom. 1:18-32}

${ }^{18}$ Sebab murka Allah nyata dari sorga atas segala kefasikan dan kelaliman manusia, yang menindas kebenaran dengan kelaliman. ${ }^{19}$ Karena apa yang dapat mereka ketahui tentang Allah nyata bagi mereka, sebab Allah telah menyatakannya kepada mereka. ${ }^{20}$ Sebab apa yang tidak tampak dari padaNya, yaitu kekuatan-nya yang kekal dan keilahian-Nya, dapat tampak kepada pikiran dari karya-Nya sejak dunia diciptakan, sehingga mereka tidak dapat berdalih. ${ }^{21}$ Sebab sekalipun mereka mengenal Allah, mereka tidak memuliakan Dia sebagai Allah atau mengucap syukur kepada-Nya. Sebaliknya pikiran mereka menjadi sia-sia dan hati mereka yang bodoh menjadi gelap. ${ }^{22}$ Mereka berbuat seolah-olah mereka penuh hikmat, tetapi mereka telah menjadi bodoh. ${ }^{23}$ Mereka menggantikan kemuliaan Allah yang tidak fana dengan gambaran yang mirip dengan manusia yang fana, burung-burung, binatang-binatang yang berkaki empat atau binatang-binatang yang menjalar. ${ }^{24}$ Karena itu Allah menyerahkan mereka kepada keinginan hati mereka akan kecemaran, sehingga mereka saling mencemarkan tubuh mereka. ${ }^{25}$ Sebab mereka menggantikan kebenaran Allah dengan dusta dan memuja dan menyembah makhluk dengan melupakan Penciptanya yang harus dipuji selama-lamanya, amin. ${ }^{26}$ Karena 
itu Allah menyerahkan mereka kepada hawa nafsu yang memalukan, sebab isteri-isteri mereka menggantikan persetubuhan yang wajar dengan yang tidak wajar. ${ }^{27}$ Demikian juga suami-suami meninggalkan persetubuhan yang wajar dengan isteri mereka dan menyala-nyala dalam berahi mereka seorang terhadap yang lain, sehingga mereka melakukan kemesuman, lakilaki dengan laki-laki, dan karena itu mereka menerima dalam diri mereka balasan yang setimpal untuk kesesatan mereka. ${ }^{28}$ Dan karena mereka tidak merasa perlu untuk mengakui Allah, maka Allah menyerahkan mereka kepada pikiran-pikiran yang terkutuk, sehingga mereka melakukan apa yang tidak pantas: ${ }^{29}$ penuh dengan rupa-rupa kelaliman, kejahatan, keserakahan dan kebusukan, penuh dengan dengki, pembunuhan, perselisihan, tipu muslihat dan kefasikan. ${ }^{30}$ Mereka adalah pengumpat, pemfitnah, pembenci Allah, kurang ajar, congkak, sombong, pandai dalam kejahatan, tidak taat kepada orang tua, ${ }^{31}$ tidak berakal, tidak setia, tidak penyayang, tidak mengenal belas kasihan. ${ }^{32}$ Sebab walaupun mereka mengetahui tuntutantuntutan hukum Allah, yaitu bahwa setiap orang yang melakukan hal-hal demikian, patut dihukum mati, mereka bukan saja melakukannya sendiri, tetapi mereka juga setuju dengan mereka yang melakukannya.

\section{Awal yang Mengejutkan}

Mengejutkan, bahwa setelah menyampaikan tesis umum suratnya (Rom. 1:16-17) yang memaparkan relasi antara Injil dan kebenaran Allah yang menyelamatkan setiap orang yang percaya, Paulus tiba-tiba menunjukkan adanya pewahyuan murka Ilahi dalam teks perikop Rom. 1:18-32. Perikop ini secara terang-terangan menyampaikan pewahyuan murka Ilahi yang dikisahkan dalam suatu narasi tertutup. Dalam teks ini Paulus menyatakan bahwa murka Ilahi diwahyukan dari surga. Tujuan pewahyuan ini adalah semua yang merusak kebenaran dalam wujud ketidakadilan atau hal-hal jahat.

Penempatan murka Ilahi yang diwahyukan ini tentu mengejutkan mengingat yang disampaikan Paulus bisa dikatakan merupakan bagian penjelasan Injil. Jika Injil merupakan hal positif, bahkan bermakna Kabar Gembira, yang seharusnya menjanjikan pengharapan, bagaimana mungkin Paulus mengawali suratnya dengan sesuatu yang demikian buruk, yaitu bahwa segala sesuatunya tidak bisa lepas dari murka Ilahi? 
Demi menjaga citra baik Injil dan ajarannya, mungkin lebih baik jika Paulus mengawali suratnya dengan teks Rom. 3:21-4:25. Perikop tersebut menyatakan bahwa "manusia dibenarkan karena iman". Salah satu yang dibenarkan menurut Paulus adalah Abraham, dengan segala keterbatasan manusiawinya. Dapat dibayangkan, jika Paulus menempatkan teks terkait pembenaran iman ini di awal suratnya, pembaca suratnya dapat lebih disiapkan untuk membaca bagian yang keras, pesimis, dan sinis terkait pewahyuan murka Ilahi itu. Akan tetapi, rupanya Paulus memiliki alasan tersendiri dalam menempatkan teks penuh amarah itu pada awal suratnya.

Alasan utama Paulus lebih suka mengawali suratnya dengan cara demikian negatif, bukanlah karena pesimismenya akan kondisi negatif terkait antropologi jemaatnya saat itu, melainkan kesungguhannya untuk menyingkirkan terlebih dahulu di awal, segala jenis cacat-cela manusiawi yang tidak sesuai dengan pewartaan Injil. Bisa jadi, cacat-cela yang dibeberkan Paulus di awal suratnya ini tidak berpengaruh besar di dalam budaya atau lingkup sosial manusia di zaman ini. Akan tetapi, Paulus berpikir dan memikirkan jemaatnya dari sudut budaya mereka saat itu, yaitu budaya Yahudi.

Bagi masyarakat Yahudi saat itu, cacat-cela semacam itu merupakan aib besar yang sangat memprihatinkan. Keprihatinan itu berkaitan erat dengan posisi bangsa Yahudi di antara bangsa-bangsa lainnya di kawasan Timur Tengah. Sebagai bangsa pilihan (1Ptr. 2:6), bangsa Israel haruslah tampil sempurna tanpa cacat-cela di hadapan bangsa-bangsa lain yang bukan bangsa terpilih. Dengan kata lain, ini berkaitan dengan gengsi identitas kebangsaan mereka yang harus selalu tampil sempurna.

Salah satu pertanyaan yang patut dikedepankan adalah ditujukan kepada siapakah murka Ilahi itu sebenarnya? Apakah ditujukan kepada bangsa Yahudi saja? Apakah murka ini dialamatkan kepada bangsabangsa lain (kafir) secara umum? ${ }^{5}$ Dalam uraian selanjutnya, pertanyaanpertanyaan itu akan memperoleh jawabannya berikut beberapa masalah lain yang akan tampil menyusul menyertainya.

\section{Pembatasan dan Komposisi Teks}

Dalam Kitab Suci terbitan LAI-LBI tampak jelas sekali pembatasan teks ini. ${ }^{6}$ Pembatasan itu tampak dengan adanya pemberian judul "Hukuman Allah atas kefasikan dan kelaliman manusia" dan pemisahannya dari perikop yang mendahului (Rom. 1:16-17) dan yang mengikutinya (Rom. 
2:1-16). Dari tinjauan tata bahasa (asli - Yunani), bagian narasi cacat-cela ini sangat kompak. Kekompakan itu terlihat dari penggunaan kata ganti orang ketiga baik tunggal maupun jamak. Artinya, jelas bahwa teks ini berbicara bukan tentang orang pertama atau orang kedua, baik tunggal maupun jamak.

Kekompakan semacam itu tidak terlihat dalam perikop terdahulu, yang menggunakan kata ganti orang pertama tunggal (Rom. 1:16 - "Sebab aku ...”). Juga tidak terlihat dalam perikop selanjutnya, yang menggunakan kata ganti orang kedua (Rom. 2:1 - "Karena itu, hai manusia ...”). Kata ganti orang ketiga tunggal maupun jamak ini digunakan untuk menyebut baik Allah maupun manusia. Selain itu, dari sudut penggunaan tempus tata bahasa dalam teks asli, bagian ini secara kompak pula menggunakan waktu lampau (past tense), sedangkan perikop selanjutnya menggunakan waktu kini dan masa depan (present tense dan future tense).

Selain itu, dari sudut pandang tokoh yang berperan dalam bagian ini, bisa ditemukan dua tokoh. Kedua tokoh yang berperan dalam perikop ini adalah Allah dan manusia. Yang dimaksudkan manusia di sini adalah manusia secara umum (tidak dibatasi asal-usul etno-religius, Yahudi maupun Yunani). Pembedaan kriteria manusia dalam teks ini tidak dilihat dari sudut pandang etnis atau religiusitas, tetapi lebih dilihat dari sisi kualitas tindakan yang dilakukannya. Secara lebih jelas, dapat dilihat tindakan yang dilakukan kedua karakter (Allah dan manusia) dalam bagian ini dalam tabel di bawah ini.

\begin{tabular}{|l|l|}
\hline \multicolumn{1}{|c|}{ Tindakan Manusia } & \multicolumn{1}{c|}{ Pembalasan Allah } \\
\hline - jahat $(1: 21-23)-3$ ayat & - negatif $(1: 24)-1$ ayat \\
\hline - jahat $(1: 25)-1$ ayat & - negatif $(1: 26-27)-2$ ayat \\
\hline - jahat $(1: 28 a)-1 / 2$ ayat & - negatif $(1: 28 b-31)-4$ ayat \\
\hline
\end{tabular}

Dari tabel terlihat bahwa yang mengawali atau mengambil inisiatif tindakan jahat adalah manusia. Tindakan yang diambil Allah tampak lebih merupakan reaksi atas inisiatif jahat manusia tersebut. Walaupun bisa dikategorikan negatif, sebenarnya tindakan pembalasan Allah itu cenderung merupakan konsekuensi atas inisiatif jahat manusia. Artinya, demikian jahatnya tindakan manusia, sehingga Allah tidak bisa lagi melakukan apapun kecuali 'menyerahkan' manusia pada kondisi-kondisi negatif. 
Bagian selanjutnya dari tulisan ini, terutama teks Rom. 1:24 menjelaskan bahwa tindakan Allah terjadi sebagai wujud partisipasinya dalam tindakan manusia yang kelewat batas (demikian jahatnya). Tindakan-tindakan manusia itu terbilang 'jahat' karena masuk kategori tidak wajar. Tindakan tidak wajar itu terwujud dalam idolatria dan perilaku seksual yang melawan sifat alamiah manusia.

Selain dapat dilihat dari tabel, 'jual-beli' tindakan antara manusia dengan Allah itu juga dapat dipantau dari komposisi perikop. Menurut U. Wilckens $^{7}$ yang dikomentari S. Lyonnet ${ }^{8}$, teks perikop Rom. 1:18-32 ini membentuk suatu komposisi konsentris.

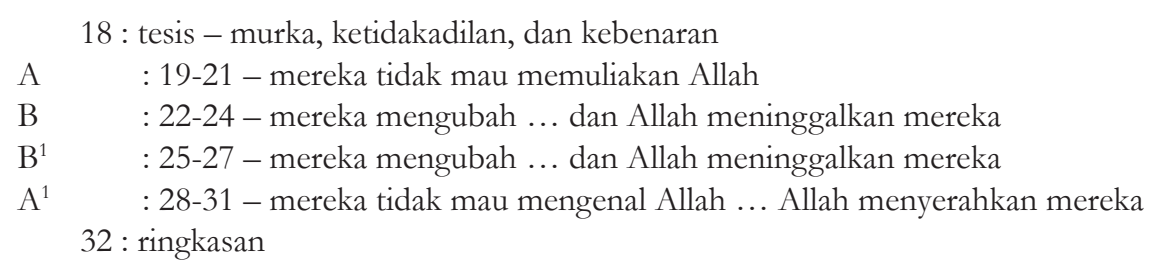

Komposisi itu menampakkan bahwa manusia ('mereka') terlebih dahulu bertindak alias berinisiatif. Sementara, Allah memberikan balasan berupa suatu konsekuensi kondisi akibat inisiatif jahat manusia itu.

\section{Allah Inkonsisten?}

Selanjutnya, tulisan ini membahas bagian per bagian proses pewahyuan murka Ilahi ini terjadi secara lebih rinci.

Teks Rom. 1:18 - "Sebab murka Allah nyata dari sorga atas segala kefasikan dan kelaliman manusia, yang menindas kebenaran dengan kelaliman" - merupakan propositio ${ }^{9}$ dari blok teks Rom. 1:18-3:20. Yang langsung tampak berbeda tajam dengan bagian yang mendahuluinya (Rom. 1:16-17) adalah nadanya yang keras, pesimis, dan sinis seperti yang telah diisyaratkan pada bagian awal tulisan ini. Pada tesis awal teks Rom. 1:1617 dinyatakan bahwa keselamatan berlaku bagi siapapun yang benar dan percaya. Dengan kata lain, tesis awal itu seolah menjadi penjamin bahwa semua manusia akan leluasa memperoleh keselamatan Ilahi. Oleh karena itu, tidaklah mengherankan jika muncul pertanyaan, bagaimana mungkin pernyataan ini begitu cepat berubah pada bagian berikutnya. Apakah dalam hal ini Allah bertindak secara inkonsisten? 
Dari teks sebenarnya terlihat bahwa perubahan tekanan dari lembut ke keras (pesimis-sinis) ini sudah dinetralkan dengan kata sambung ' $g a r^{\prime}$ (sebab). Kata ini tidak berfungsi menegasikan atau memperlawankan tesis awal dengan tesis dalam bagian ini. Fungsinya justru melanjutkan tesis awal tersebut demi pewartaan yang lebih spesifik ${ }^{10}$. Kesan yang berubah secara tajam ini juga dinetralkan dengan munculnya kata 'apokalyptetai' (diwahyukan) secara nyata yang juga terdapat dalam teks Rom. 1:17 - Sebab di dalamnya nyata (apokalyptetai) ... Kata ini berfungsi sebagai pengait kedua propositio itu. Selain itu, juga dua kata yang berpasangan, yaitu pada teks Rom.1:16, 'panti'(setiap) dan teks Rom. 1:18, 'pasan' (segala). Dari dua kata yang berpasangan itu, dapat ditampilkan suatu pernyataan bahwa 'keadilan Allah bukan hanya bagi keselamatan setiap (panti) orang yang percaya, melainkan juga bagi segala (pasan) kefasikan dan kelaliman manusia"11. Dengan kata lain, dalam ayat ini hendak dinyatakan bahwa keadilan Allah yang diwahyukan, saat berjumpa dengan ketidakadilan dan tindakan tidak wajar yang dilakukan manusia berubah menjadi kemarahan, bukan belas kasihan. Kondisi semacam itu dapat juga dilihat dalam teks Rom. 3:4 yang berbunyi "Sebaliknya: Allah adalah benar, dan semua manusia adalah pembohong".

Mulai teks Rom. 1:19 - "Karena apa yang dapat mereka ketahui tentang Allah nyata bagi mereka, sebab Allah telah menyatakannya kepada mereka" - terjadilah pertukaran aktivitas-tindakan Allah-manusia. Yang patut diperhatikan adalah aksentuasi dan tekanan pada akhir daftar cacatcela yang menampilkan hukuman Allah (Rom. 1:32). Teks Rom. 1:19 ini memulai narasi cacat-cela dengan hal positif, yaitu pernyataan bahwa semua memiliki kemungkinan mengenal Allah. Dijumpai pula strategi retorika dalam wujud pengulangan etimologis kata yang berakar sama, yaitu 'phaneroun' (nyata) dan 'ephanerosen' (menyatakan). Dua kata serupa yang diulang ini dalam strategi retorika biasanya hendak menekankan sesuatu yang penting. Dalam hal ini, pengetahuan tentang Allah merupakan hal nyata yang sangat penting.

Paulus memunculkan hapax legomenon (kata yang hanya muncul di satu teks) di sini, yaitu 'to gnōston' guna menyebut ungkapan 'apa yang dapat mereka ketahui'. Walaupun diawali dengan kata pembentuk kata benda 'apa yang', kata ini bukanlah kata benda, melainkan suatu pernyataan bahwa tidak semua hal yang berkaitan dengan Allah bisa diketahui manusia. 
Dengan kata lain, hendak disampaikan bahwa pemahaman manusia akan Allah sangat terbatas. Pemahaman manusia akan Allah tidak komprehensif alias tidak menyeluruh.

\section{Bukti Keberadaan Allah}

Teks Rom. 1:20 - "Sebab apa yang tidak tampak dari pada-Nya, yaitu kekuatan-nya yang kekal dan keilahian-Nya, dapat tampak kepada pikiran dari karya-Nya sejak dunia diciptakan, sehingga mereka tidak dapat berdalih" - ini merupakan bagian pertama narasi yang memaparkan bahwa Allah (yang tidak terlihat) dibuktikan keberadaannya melalui karya-Nya. Ini merupakan upaya menggemakan teks "5Sebab orang dapat mengenal Khalik dengan membanding-bandingkan kebesaran dan keindahan ciptaan-ciptaanNya. ${ }^{6}$ Namun demikian dalam hal ini mereka hanya sedikit saja salahnya, sebab mungkin mereka hanya tersesat, tetapi mereka mencari Allah dan berusaha menemukanNya" (Keb. 13:5-6). Pernyataan di luar konteks biblis juga menggemakan pernyataan ini. Salah satunya adalah pernyataan Marcus Tullius Cicero, yaitu " $u t$ deum non vides, tamen, ut deum adgnoscis ex operibus eius ..." Paulus tidak secara khusus mengarahkan perikop ini bagi bangsa Yahudi saja, tetapi terutama kepada manusia pada umumnya.

Dari sudut pandang intra-Yahudi, Yosephus Flavius membaca ulang hubungan Allah dengan ciptaan-Nya ini dalam ungkapan "Musa telah menunjukkan bahwa Allah itu satu, tidak dijadikan, dan tidak bisa diubah selama-lamanya. Dengan cara yang indah dan mengagumkan Allah berada di atas segala bentuk kematian. Ia dikenali melalui kekuatan-Nya, tetapi tidak dikenali dalam keberadaan-Nya"13.

Terdapat pula hapax legomenon dari Perjanjian Baru di sini, yaitu 'kathoran'. Dengan kata yang berarti 'tampak kepada pikiran' atau 'mengkontemplasikan', Paulus dengan ini hendak menggarisbawahi keterbatasan antropologis manusia dalam memahami Allah.

Teks Rom. 1:21 - "Sebab sekalipun mereka mengenal Allah, mereka tidak memuliakan Dia sebagai Allah atau mengucap syukur kepada-Nya. Sebaliknya pikiran mereka menjadi sia-sia dan hati mereka yang bodoh menjadi gelap" - menjelaskan bahwa tindakan positif Allah terwujud dalam karya-Nya tetapi tidak dipahami manusia secara menyeluruh. Akibatnya, tidak ada pujian bagi Allah yang datang dari manusia. Pada 
bagian kedua narasi ini, tuduhan Paulus atas terjadinya ketidakpahaman manusia akan Allah itu terarah pada hati manusia. Menurut Paulus, hati manusia merupakan sumber bahaya dan kegelapan. Hati manusia merupakan organ utama. Jika organ utama ini tidak berfungsi atau mengalami penyimpangan fungsi, anggota tubuh lainnya akan terganggu. Aneh bahwa Paulus menggunakan kata 'gelap' untuk melukiskan keadaan hati manusia. Pemilihan kata ini aneh. Seharusnya kata 'gelap' digunakan untuk sesuatu yang menyangkut penglihatan atau pandangan. Misalnya, "Dan biarlah mata mereka menjadi gelap, sehingga mereka tidak melihat, dan buatlah punggung mereka terus-menerus membungkuk" (Rom. 11:10) atau "Biarlah mata mereka menjadi gelap, sehingga mereka tidak melihat; buatlah pinggang mereka goyah senantiasa!” (Mzm. 69:24).

Rupanya dengan menggunakan kata 'gelap' Paulus ingin menyampaikan gagasan yang lain. Menurutnya, kualitas mata manusia sangat tergantung dari berfungsinya hati secara baik. Hati yang baik akan menghasilkan mata yang baik. Demikian sebaliknya. Hati yang gelap menghasilkan mata yang gelap pula. Selain itu, Paulus juga ingin menekankan sisi antropologis Yahudi. Dalam antropologi Yahudi, manusia berpikir dengan hatinya, memerintah dengan kepalanya, dan hal-hal yang berkaitan dengan perasaan muncul dari sekitar isi perut manusia. Oleh karena itu, pengetahuan (synesis) dan mereka yang memiliki pengetahuan (synetoi) berlawanan dengan mereka yang tebal hati (asynetoi).

\section{Kebodohan Manusia: Idolatria}

Kekurangan pengetahuan mengakibatkan kebodohan. Ini berlaku bagi semua kondisi fisik maupun psikis manusia, termasuk mereka yang merasa diri seolah-olah tidak bodoh atau merasa diri berpengetahuan. Kata 'seolah-olah' atau secara harafiah dapat diterjemahkan menjadi 'menduga diri' (phaskein) muncul hanya tiga kali dalam Perjanjian Baru. Satu dalam teks ini. Dua lainnya dijumpai dalam teks Kis. 24:9 ("Dan juga orang-orang Yahudi menyokong [phaskontes] dakwaan itu dengan mengatakan, bahwa perkara itu sungguh demikian") dan teks Kis. 25:19 ("Tetapi mereka hanya berselisih paham dengan dia tetnang soal-soal agama mereka, dan tentang seorang bernama Yesus, yang sudah mati, sedangkan Paulus katakan dengan pasti [ephasken], bahwa Ia hidup").

Sedangkan kata 'bodoh' dalam teks ini beranalog dengan kata 'bodoh' 
dalam teks 1 Kor. 1:18 yang menggemakan teks Keb. 11:15, yaitu "Oleh karena pikiran-pikiran mereka yang bodoh dan jahat, yang menyesatkan orang-orang Mesir hingga memuja binatang melata yang tidak berakal serta hewan yang keji, maka telah Kau kirim kepada mereka banyak binatang yang tidak berakal sebagai hukuman".

Kata kerja 'menjadi' yang muncul berpasangan dalam teks Rom. 1:21 dan teks Rom. 1:22 menjadi pembuka suatu situasi yang baru atau perubahan, yaitu " ${ }^{21}$ hati mereka yang bodoh menjadi gelap ... ${ }^{22}$ mereka telah menjadi bodoh"14. Ini merupakan suatu bentuk strategi retorika lain yang ditampilkan Paulus. Strategi retorika ini dianalogikan dengan klaim kebenaran yang diajukan dalam persidangan. Saat hendak ditegaskan kebenarannya, klaim tersebut harus menjalani pemeriksaan berdasarkan bukti-bukti yang akurat dan legal. Sebagai catatan, dalam Perjanjian Lama, kata 'bodoh' kerap bermakna tidak mengenal Allah. Ungkapan ini antara lain ditemukan dalam teks "Oleh karena pikiran-pikiran mereka yang bodoh dan jahat, yang menyesatkan orang-orang Mesir hingga memuja binatang melata yang tidak berakal serta hewan yang keji, maka telah kaukirimkan kepada mereka banyak binatang yang tidak berakal sebagai hukuman" (Keb. 11:15). Proses membuktikan bahwa hati yang bodoh akan menjadi gelap sekaligus bodoh dijelaskan dalam teks berikutnya.

Kegelapan hati manusia menggiringnya ke arah penyembahan berhala (idolatri). Dalam hal ini, tuduhan Paulus ditujukan kepada semua yang gelap hatinya. Dengan tuduhannya, seolah-olah Paulus menggemakan teks Mzm. 106:18-20, yaitu " ${ }^{18}$ Api menyala di kalangan mereka, nyala api menghanguskan orang-orang fasik itu. ${ }^{19}$ Mereka membuat anak lembu di Horeb, dan sujud menyembah kepada patung tuangan; ${ }^{20}$ mereka menukar Kemuliaan mereka dengan bangunan sapi jantan yang makan rumput." Sebenarnya, Mazmur itu sendiri menjemput kisah dalam teks Kej. 32 yang melukiskan terjadinya suatu sinkretisme idolatri Yahudi-kafir.

Dalam teks Rom. 1:23 - "Mereka menggantikan kemuliaan Allah yang tidak fana dengan gambaran yang mirip dengan manusia yang fana, burung-burung, binatang-binatang yang berkaki empat atau binatangbinatang yang menjalar" - Paulus membuat dua kategori idolatri. Pertama, gambaran manusia. Kedua, hewan. Patut diperhatikan bahwa gambaran idolatri hewan ini dituliskan seolah-olah seturut perkembangan evolutif. Pertama, burung. Ini sepertinya hendak menampilkan kembali sosok dewa 
Ibis (dewa terbang) dari Mesir. Kedua, hewan berkaki empat. Ini sepertinya mau menampilkan sosok banteng yang banyak ditemui dalam budaya Timur Tengah kuno. Ketiga, reptil. Bisa jadi ini mengarah pada sosok buaya yang biasa ditokohkan bangsa Mesir kuno. Lukisan aneka idolatri ini menggemakan kembali gambaran idolatri khas Tradisi Deuteronomistik yang terungkap dalam teks " ${ }^{\text {"sib }}$ supaya jangan kamu berlaku busuk dengan membuat bagimu patung yang menyerupai berhala apa pun: yang berbentuk laki-laki atau perempuan; ${ }^{17}$ yang berbentuk binatang yang di bumi, atau berbentuk burung bersayap yang terbang di udara, ${ }^{18}$ atau berbentuk binatang yang merayap di muka bumi, atau berbentuk ikan yang ada di dalam air di bawah bumi” (Ul. 4:16-18).

\section{Murka Allah Hadir}

Kini tindakan Allah hadir dalam murka-Nya. Paulus menggunakan kata 'paradidomi' dalam ayat ini dengan suatu intensi khusus. Kata 'paradidōmi yang digunakan Paulus untuk mengungkapkan ekspresi 'menyerahkan' mengandaikan adanya partisipasi objek dalam tindakan tersebut bersama dengan si subjek. Dengan kata lain, ada kerja sama antara objek dan subjek. Tindakan tersebut bukanlah tindakan sepihak. Allah menyerahkan manusia karena dari dalam diri manusia sendiri telah terdapat kecenderungan ke arah itu. Origenes memperkuat dugaan ini dengan menyatakan bahwa "kenyataan bahwa manusia diserahkan adalah terutama karena keinginan hati mereka sendiri" ${ }^{15}$. Walaupun demikian, ungkapan 'keinginan' (epithymia) sebenarnya tidak selalu berkonotasi negatif. Supaya pemahaman makna 'keinginan' bisa lebih tajam teks Flp. 1:23 - "Aku didesak dari dua pihak: aku ingin pergi dan diam bersamasama dengan Kristus - itu memang jauh lebih baik" dapat dipakai sebagai pembandingnya. Kata 'cemar' (akatharsia) merupakan istilah moral khas Paulus. Ekspresi ini menunjuk pada suatu nafsu atau hasrat yang negatif. Kecemaran yang didorong hasrat negatif ini menyangkut tiga hal. Pertama, makanan. Kedua, ibadat. Ketiga, seksualitas.

Kalimat akhir teks Rom. 1:24 - "sehingga mereka saling mencemarkan tubuh mereka" - sulit ditafsirkan karena subjek utamanya adalah Allah. Ada dua kemungkinan pengertian. Pertama, 'saling mencemarkan tubuh mereka' ini merupakan konsekuensi dari tindakan menyerahkan yang dilakukan Allah. Dalam hal ini, suatu tindakan menimbulkan akibat atau 
konsekuensi, yaitu kecemaran. Kedua, 'saling mencemarkan tubuh mereka' dapat juga merupakan tujuan tindakan menyerahkan yang dilakukan Allah. Dengan kata lain, aktivitas yang dilakukan Allah memang bertujuan supaya manusia saling mencemarkan diri. Jika yang terjadi adalah kemungkinan kedua, dapat dibayangkan betapa jahat-nya Allah sehingga sengaja menjerumuskan manusia pada kecemaran. Oleh karena itu, sebaiknya kalimat itu dipahami bahwa Allah tidak menyerahkan mereka supaya tidak mencemari tubuh mereka. Akan tetapi, kecemaran itu terjadi sebagai suatu akibat langsung (konsekuensi logis) tindakan penyerahan yang dilakukan Allah. Penafsiran ini harus selalu dikaitkan pada makna kata penyerahan itu (paradidomi) yang merupakan tindakan partisipatif subjek-objek.

Pada bagian ketiga narasi ini, Paulus langsung pada titik permasalahan, yaitu penyembahan berhala. Paulus tidak membenarkan sama sekali tindakan manusia ini. Paulus menggunakan dua kata guna menyebut praktik penyembahan berhala itu, yaitu 'sebazethai' dan 'latreuein'. Kata yang pertama merupakan hapax legomenon yang berarti adorasi atau penghormatan dalam arti umum. Kata ini seharusnya hanya digunakan untuk Allah. Kata yang kedua merupakan tindakan yang lebih khusus, yaitu beribadat. Dengan kata lain, ada formulasi kata atau tata liturgis yang terkandung di dalam aktivitas tersebut. Dengan mengacu pada ibadat-ibadat tradisional Yahudi, Paulus menegaskan bahwa baik dalam makna umum maupun dalam makna khusus, segala macam bentuk adorasi, penghormatan, atau ibadat tidak boleh diberikan kepada subjek lain selain Allah. Jika aktivitas itu dilakukan, terjadilah idolatria alias penyembahan berhala.

Di akhir ayat muncul formulasi berkat ilahi yang ditutup dengan kata 'amin'. Formulasi berkat ilahi yang serupa bisa ditemukan dalam teks "Mereka adalah keturunan bapa-bapa leluhur, yang menurunkan Mesias dalam keadaan-Nya sebagai manusia, yang ada di atas segala sesuatu. Ia adalah Allah yang harus dipuji sampai selama-lamanya. Amin!” (Rom. 9:5). Formulasi ini muncul bukan sebagai penutup suatu doa, pernyataan, atau suatu persetujuan, melainkan ungkapan spontan Paulus yang mengenal Allah sebagai satu-satunya yang harus disembah. Bagi Paulus kata 'amin' ini harus spontan muncul saat dirinya menyampaikan suatu pengakuan iman. Kata 'amin' ini sengaja dimunculkan guna menutup bagian narasi terkait idolatria ini. Dengan menutup bagian terkait idolatri ini, Paulus bermaksud maju terus untuk menjelaskan konsekuensi yang ditanggung manusia sebagai akibat dari idolatria yang mereka lakukan. 


\section{Kebebalan Seksual}

Guna menjelaskan konsekuensi yang harus ditanggung akibat idolatria ini, Paulus memulai ayat ini dengan melakukan spesifikasi kecemaran. Digunakan Paulus dua kata 'pathos' (nafsu atau hasrat) dan 'atimia' (cemar atau tidak hormat). Dalam tata bahasa, jika dua kata ini digabungkan menjadi 'pathe atimias', yang terjadi adalah bentukan genitif kualitatif. Dengan demikian, 'pathe atimias' sebenarnya berarti 'hasrat akan kecemaran' atau 'hasrat yang tidak terhormat alias memalukan"16. Paulus sendiri kerap menyebutnya sebagai 'kebebalan seksual'.

Bagian kedua ayat ini mengawali daftar kebebalan seksual dengan suatu kata sambung ' $g a r$ '. Kata sambung ini sebenarnya lebih berfungsi sebagai penjelas ('yaitu'), bukan ('sebab'). Kebebalan seksual pertama yang disebut adalah homoseksualitas feminin. Ini dimunculkan untuk menghantar pada homoseksualitas maskulin yang terdapat di ayat berikutnya (Rom. 1:27) ${ }^{17}$. Paulus tidak bermaksud menjelaskan segala sesuatu terkait penyimpangan yang dilakukan kaum perempuan, dengan menempatkan homoseksualitas feminin ini sebagai yang pertama ${ }^{18}$. Diduga kuat, Paulus memasang homoseksualitas feminin sebagai yang pertama dengan alasan kesetaraan gender. Ini sekaligus menunjukkan mulai menyusupnya pengaruh budaya modern di dalam budaya Yahudi yang patriarkis. Ini sekaligus merupakan catatan pertama tentang homoseksualitas feminin pada masa sebelum 70 Masehi. Tidak ada catatan apapun tentang hal ini dalam Perjanjian Lama. Dengan kata lain, Perjanjian Lama tutup mulut alias melakukan tindakan 'silentium' terkait siapa pelaku utama dosa-dosa manusia. Di sisi lain, teks ini sebenarnya juga ingin menggemakan kembali persoalan siapa yang salah dalam kisah kejatuhan manusia (Kej. 3). Akan tetapi, sebenarnya Paulus mau menyasar hal yang lebih mendasar dari sekadar homoseksualitas feminin, yaitu dosa melawan 'kodrat'.

Dalam teks Rom. 1:27 - "Demikian juga suami-suami meninggalkan persetubuhan yang wajar dengan isteri mereka dan menyala-nyala dalam berahi mereka seorang terhadap yang lain, sehingga mereka melakukan kemesuman, laki-laki dengan laki-laki, dan karena itu mereka menerima dalam diri mereka balasan yang setimpal untuk kesesatan mereka" - muncul menyusul homoseksualitas maskulin. Dalam hal ini, Perjanjian Lama ikut berbicara, bahkan meng-undang-undangkan-nya dalam teks Im. 18:22 
("Janganlah engkau tidur dengan laki-laki secara orang bersetubuh dengan perempuan, karena itu suatu kekejian.” ${ }^{19}$. Seperti halnya homoseksualitas feminin, yang hendak disasar Paulus sebenarnya adalah perlakuan terhadap tubuh yang tidak sesuai dengan kodrat manusia. Paulus menggunakan kata yang janggal untuk menggambarkan gairah atau hasrat seksual yang negatif, yaitu dengan kata 'ekkaiomai' (menyala-nyala). Untuk pertama kalinya Paulus menggunakan metafora api guna menunjukkan hasrat seksual. Dalam metafora api pula, tetapi dalam konteks berbeda, Paulus juga menggandengkannya dengan hasrat seksual ("Tetapi kalau mereka tidak dapat menguasai diri, baiklah mereka kawin. Sebab lebih baik kawin dari pada hangus karena hawa nafsu" - 1Kor. 7:9).

Memang, dalam teks Rom. 1:27 Paulus belum membedakan secara tegas antara kecenderungan dan perbuatan seperti yang biasa dilakukan pada era post-freudiana, yang menyatakan bahwa kecenderungan masih bisa dimaafkan, sementara tindakan akan mendatangkan hukuman ${ }^{20}$. Sekali lagi ditegaskan bahwa yang disasar Paulus bukanlah homoseksualitas itu sendiri, melainkan tindakan yang menyimpang, yang berbalikan dengan kehendak Allah. Paulus tidak berangkat dari homoseksualitas guna sampai pada gagasan penyembahan berhala. Sebaliknya, Paulus menunjukkan bahwa penyembahan berhala terjadi sebagai akibat penyimpangan penghayatan relasi antara Allah dengan manusia yang tercermin dalam penyimpangan seksual. Dengan kata lain, tindakan manusia menyimpang karena relasinya dengan Allah buruk. Pada ayat ini, bagian ketiga narasi ditutup.

Dalam teks Rom. 1:28 - "Dan karena mereka tidak merasa perlu untuk mengakui Allah, maka Allah menyerahkan mereka kepada pikiran-pikiran yang terkutuk, sehingga mereka melakukan apa yang tidak pantas murka Allah telah menjadi noda hitam yang melekat pada diri manusia" - Paulus menyasar pikiran manusia yang tidak memiliki kepenuhan pemahaman akan Allah sebagai biang keladi permasalahan, sehingga pikiran itulah yang diserahkan kepada pikiran-pikiran terkutuk. Yang dimaksudkan Paulus dengan pikiran-pikiran terkutuk diungkapkan dengan dua kata, yaitu 'dokimazein' (berdiskresi) dan 'epignōsis' (berpengetahuan utuh) dalam makna sebaliknya. Artinya, mereka yang berpikiran terkutuk itu tidak sanggup untuk berdiskresi dan tidak memiliki pengetahuan yang utuh atau 
penuh tentang Allah dan kehendak-Nya.

Teks Rom. 1:29-32 merupakan yang paling pesimistis dalam Surat-surat Paulus. Tercatat ada 21 cacat-cela. Dalam konteks ini, angka 21 merupakan suatu jumlah yang buruk. Jumlah 21 terjadi sebagai hasil tiga kali tujuh (3 X 7) cacat-cela. Menurut tradisi Yahudi, tiga menjadi ungkapan penyangatan atau secara negatif berarti keterlaluan. Sedangkan, tujuh adalah lambang kesempurnaan. Dalam konteks ini, yang dimaksud dengan dengan daftar 21 cacat-cela itu adalah cacat yang sangat sempurna atau cacat yang sangat negatif. Cacat-cela ini meliputi seluruh wilayah utama manusia, kecuali wilayah seks yang telah disebut di awal. ${ }^{21}$ Dari skema atau urut-urutannya, kemungkinan besar daftar ini diambil dari Perjanjian Lama (bdk. Kel. 20:1317; Ul. 5:17-21). Cacat-cela ini pun diurutkan sembarangan, tanpa urutan yang jelas. Ini sekaligus menunjukkan amburadulnya kualitas manusia yang melakukan cacat-cela tersebut.

\section{Epilog}

Dari perikop Rom. 1:18-32 ditegaskan bahaya yang akan merasuki diri manusia akibat penyimpangan hubungannya dengan Allah. Terjadi perkembangan negatif bahwa tindakan-tindakan menyimpang atau negatif yang dilakukan manusia lama-kelamaan akan menjadi sifat negatif yang bersarang dalam dirinya alias menjadi cacat-celanya.

Hukuman Allah pantas diterima manusia karena merupakan konsekuensi logis atas penyimpangan yang dilakukannya (buruknya relasi mereka dengan Penciptanya). Dengan kata lain, kejahatan manusia berkonsekuensi murka Allah. Murka Allah ini bukanlah komponen penghakiman (bukan perkara di meja pengadilan), melainkan hubungan antara Pencipta dan ciptaan-Nya yang buruk. Ini berkaitan dengan penyimpangan kodrat ciptaan.

\section{Bibliography}

\section{Instrumen-Sumber Biblis:}

Aland, K. - Black, M. - Martini, C.M. - Metzger, B.M. - Wickgren, A. The Greek New Testament. New York-London-Edinburgh-AmsterdamStuttgart: UBS, 1993. 
Catechismus Catholica Ecclesice. Città del Vaticano: Libreria Editrice Vaticana, 1997.

Zerwick, M. - Grosvenor. A Grammatical Analysis of the Greek New Testament. Roma: PIB, 1981.

\section{Bibliografi Pontifikal:}

Kongregasi Ajaran Iman. Declaratio de quibusdam questionibus ad sexualem ethicam spectantibus. SC Pro Doctrina Fidei, 29-12-1975. AAS 68 (1976) diterjemahkan Piet Go O. Carm dari bahasa Latin. Jakarta: Departemen Dokumentasi dan Penerangan Konferensi Waligereja Indonesia, 2005. Considerations Regarding Proposals to give Legal Recognition to Unions between homosexual Persons. June 3, 2003 no.4.

Paus Fransiskus. Seruan Apostolik Pascasinode 19 Maret 2016, Amoris Latitia - Sukacita Kasih. Jakarta: Departemen Dokumentasi dan Penerangan Konferensi Waligereja Indonesia, 2017.

\section{Bibliografi Klasik:}

Cicerone, Le Tusculane. E. Narducci - L.Z. Clerici (eds.). Milano: BUR, Rizzoli, 1996.

Flavio Giuseppe. La guerra gindaica. G. Vitucci (ed.), Milano: VallaMondadori, Milano $1989^{4}$.

Origene. Commentaria in epistolam b. Pauli ad Romanos. PG 14, coll.837-1291, I: $42-43$.

Platone, Timaeus. G. Lozza (ed.). Milano: Mondadori, 1994.

Pseudo-Aristoteles. De Mundo. D.J. Furley (ed.). LCL. Cambridge-London: Harward University Press, 1977.

\section{Bibliografi Modern:}

Aletti, J.-N. Comment Dieu est-il juste? Clefs pour interpréter l'épittre aux Romans. Paris: aux Éditions du Seuil, 1991.

Berger, K. "Hellenistische Gattungen im Neuen Testament." Aufstiege und Niedergang der römischen Welt II 25/2, 1031-1432, 1984.

Byrne, B. Romans. Collegeville: Sacra Pagina, Liturgical Press, 1996.

Cranfield, C.E.B. The Epistle to the Romans I. Edinburgh: T\&T Clark, 1975. 
Fauconnet, J.J. "Confrontation des vices et des vertus dans les épîtres du Nouveau Testament." Bulletin de Littérature Ecclésiastique 89, 83-96, 1988.

Finamore, S. "The Gospel and the Wrath of God in Romans 1." Understanding, Studying and Reading edited by C. Rowland - C.H.T. Fletcher-Louis (Sheffield: Journal for the Study of the New Testament 153, 138-140,1998.

Fitzmyer, J.A. Lettera ai Romani. Commentario critico-teologico. Casale Monferrato (AL): Piemme, 1999.

Lyonnet, S. "Étude sur l'Épittre aux Romains." Analecta Biblica 120. Roma: PIB, $1990^{2}$.

Miller, J.E. "The Practice of Romans I:26a: Homosexual atau Heterosexual?" In Novum Testamentum 37, 1-11, 1995.

Moo, D.J. The Epistle to the Romans. Grand Rapids: NICNT, Eerdmans, 1996.

Penna, R. (ed.). Diøionario di Paolo e delle sue lettere. Milano: Ciniselo Balsamo, 1999.

Scroggs, R. The New Testament and Homosexuality: Contextual Background for the Contemporary Debate. Philadelphia: Fortress Press, 1983.

Stowasser, M. "Homosexualität und Bibel. Exegestische und Hermeneutische Überlengungen zu einem schwierigen Thema." New Testament Studies 43, 503-526, 1997.

Wilckens, U. Der Brief an die Römer I-V. Neukirchen-Vluyn: BenzingerNeukirchener, $1987^{2}$.

\section{Endnotes:}

1 Pengajar Tafsir Kitab Suci di Fakultas Filsafat Universitas Katolik Parahyangan Bandung dan mahasiswa Program S3 Universitas Islam Negeri Sunan Gunung Djati Bandung.

2 Catechismus Catholica Ecclesice (Città del Vaticano: Libreria Editrice Vaticana, 1997).

3 AAS 68 (1976) diterjemahkan Piet Go O.Carm dari bahasa Latin Departemen Dokumentasi dan Penerangan Konferensi Waligereja Indonesia Jakarta: 2005).

4 Considerations Regarding Proposals to give Legal Recognition to Unions between homosexual Persons, Congregation for the Doctrine of the Faith, June 3, 2003 no.4.

5 Lih. J.-N. Aletti, Comment Dieu est-il juste? Clefs pour interpréter l'épittre aux Romans (Paris: aux Éditions du Seuil, 1991) 56-63. 
6 Bagi yang berminat melihat beberapa analisis pembatasan teks ini, dapat membaca J.A. Fitzmyer, Lettera ai Romani. Commentario critico-teologico (Casale Monferrato (AL): Piemme, 1999) 324-325 dan D.J. Moo, The Epistle to the Romans (Grand Rapids: Eerdmans, 1996) 95.

7 U. Wilckens, Der Brief an die RömerI-V (Neukirchen-Vluyn: Benzinger-Neukirchener, 19872) 95-96.

8 S. Lyonnet, "Étude sur l'Épître aux Romains," Analecta Biblica 120 (Roma: PIB, $\left.1990^{2}\right)$.

9 Tesis yang akan ditampilkan dengan pelbagai macam bukti. Dalam Surat-surat Paulus banyak dijumpai propositio yang terkait dengan bagian akhir sebuah exordium. Propositio ini tidak selalu mengandaikan atau mengharuskan adanya propositio lain yang sejajar.

10 Fitzmyer, op. cit., 333.

11 S. Finamore, "The Gospel and the Wrath of God in Romans 1," Understanding, Studying and Reading edited by C. Rowland - C.H.T. Fletcher-Louis (Sheffield: Journal for the Study of the New Testament, 1998) 138-140.

12 Cicerone, Le Tusculane. E. Narducci - L.Z. Clerici (eds.). (Milano: BUR, Rizzoli, 1996) 1,28,70; Platone, Timaeus. G. Lozza (ed.) (Milano: Mondadori, 1994) 28A-30C; 32A-35A; Pseudo-Aristoteles, De Mundo. D.J. Furley (ed.). LCL. (CambridgeLondon: Harward University Press, 1977) 6,397b-398b.

13 Flavio Giuseppe, La guerra gindaica, G. Viticci (ed.) (Milano: Valla-Mondadori, 19894) $7,8,7$.

14 Moo, op. cit., 107-108.

15 Origene, Commentaria in epistolam b. Pauli ad Romanos, PG 14, coll.837-1291, I, 42-43.

16 Moo, op. cit., 113.

17 B. Byrne, Romans (Collegeville: Sacra Pagina, Liturgical Press, 1996) 76; C.E.B. Cranfield, The Epistle to the Romans I (Edinburgh: T\&T Clark, 1975) 125; Fizmyer, op. cit., 344; R. Penna, (ed.) Dizionario di Paolo e delle sue lettere (Milano: Ciniselo Balsamo, 1999) 1100.

18 J.E. Miller, “The Practice of Romans I:26a: Homosexual atau Heterosexual?” Novum Testamentum 37, 1-11, (1995) 1-11.

19 M. Stowasser, "Homosexualität und Bibel. Exegestische und Hermeneutische Überlengungen zu einem schwierigen Thema," New Testament Studies 43, (1997) 503526.

20 R. Scroggs, The New Testament and Homesexuality: Contextual Background for the Contemporary Debate (Philadelphia: Fortress Press, 1983) 101-109.

21 K. Berger, "Hellenistische Gattungen im Neuen Testament," Aufstiege und Niedergang der römischen Welt II 25/2 (1984) 1031-1432 dan J.J. Fauconnet, "Confrontation des vices et des vertus dans les épîtres du Nouveau Testament," Bulletin de Littérature Ecclésiastique 89 (1988) 83-96. 